\title{
Response of Different Fertility Levels and Pre-Emergence Herbicides on Weed Population and Benefit Cost Ratio of Colocasia (Colocasia esculenta Var. antiquorum)
}

\author{
R.K. Markam, Deo Shankar* and A.K. Thakur
}

\begin{abstract}
Shaheed Gundadhoor College of Agriculture and Research Station (Indira Gandhi Krishi Vishwavidyalaya) Jagdalpur, Bastar-494 005 (Chhattisgarh), India
\end{abstract}

*Corresponding author

\begin{tabular}{|c|c|}
\hline & A B S T R A C T \\
\hline & \multirow{6}{*}{$\begin{array}{l}\text { The field experiment was conducted during the year } 2017 \text { under All India Co-ordinated } \\
\text { Research Project on Tuber Crops at S.G. College of Agriculture and Research Station, } \\
\text { Jagdalpur, IGKV, Raipur (C.G.). The experiment was laid out in split plot design with two } \\
\text { factors namely fertility levels and different pre-emergence herbicides with three } \\
\text { replications. The result revealed that weed species, weed population and dry weight of } \\
\text { weed were recorded significantly maximum under } \mathrm{F}_{5}\left(130 \% \mathrm{NPK} \text { ) followed by under } \mathrm{F}_{4}\right. \\
(115 \% \mathrm{NPK}) \text {, weed control efficiency were not affected by any fertility levels treatment. In } \\
\text { case of application of pre-emergence herbicides whereas the weed species, weed density } \\
\text { and dry weight of weed were significantly higher in } \mathrm{T}_{6} \text { (weedy check) whereas, weed } \\
\text { control efficiency was recorded significantly higher in } \mathrm{T}_{2}(\text { Pendimethalin @ } 1.5 \mathrm{~kg} \text { a.i. } \\
\left.\text { ha }^{-1}\right) \text { at } 30 \text { and } 60 \mathrm{DAP} \text {. However, net returns and benefit cost ratio was recorded } \\
\text { significantly maximum under } \mathrm{F}_{5}\left(130 \% \text { NPK) followed by } \mathrm{F}_{4}(115 \% \mathrm{NPK}) \text { and minimum }\right. \\
\text { was observed under } \mathrm{F}_{1}(70 \% \mathrm{NPK}) \text { in fertility levels. In case of pre-emergence herbicides } \\
\left.\text { recorded significantly higher under } \mathrm{T}_{2} \text { (Pendimethalin @ } 1.5 \mathrm{~kg} \text { a.i. ha }{ }^{-1}\right) \text { and lowest was } \\
\text { observed under } \mathrm{T}_{6} \text { (weedy check). }\end{array}$} \\
\hline Keywords & \\
\hline $\begin{array}{l}\text { Colocasia, Fertility } \\
\text { and pre-emergence } \\
\text { herbicides, Weed fl } \\
\text { studies, Weed cont } \\
\text { economics }\end{array}$ & \\
\hline Article Info & \\
\hline $\begin{array}{l}\text { Accepted: } \\
\text { 18 August } 2018 \\
\text { Available Online: } \\
\text { 10 September } 2018\end{array}$ & \\
\hline & \\
\hline
\end{tabular}

\section{Introduction}

Colocasia (Colocasia esculenta var. antiquorum) is a stem tuber crop that belongs to the family Araceae. It is a most important tuber vegetable of the world and is known as "Great leaved Caladium" or "Elephant ear" in English, "Dasheen" in USA and "Cocoyam" in West Africa. In Chhattisgarh it is locally known as Kochai and popularly cultivated tuber crops in the whole state. Colocasia is believed to have originated in South East Asia including India (Chang, 1958) and Malaysia (Keleny, 1962). Colocasia is one of the few edible species in the genus colocasia and is the most widely cultivated species (Vinning, 2003). Cultivated colocasia is classified as Colocasia esculenta, but the species is considered to be polymorphic.

There are two botanical varieties of taro (Purseglove, 1972) viz. Colocasia esculenta var. esculenta and Colocasia esculenta var. antiquorum. C. esculenta var. esculenta is 
characterised by the possession of a large cylindrical central corm and very few cormels. It is referred agronomically as the dasheen type of colocasia. On the other hand, C. esculenta var. antiquorum, has a small globular central corm, with several relatively large cormels arising from the corm. Plants are perennial but cultivated as annuals, lactiferous and very variable herb with $30-150 \mathrm{~cm}$ in height. Leaves are large or rather large, obliquely erect, long petiole, with varying colour and size. Petiole is sheathering at the base, uniformly light or dark green, green with dark streaks or violet, $40-150 \mathrm{~cm}$ long. It consists mainly of the leaves with long petiole which arises in a whorl from the apex of the underground corm. Corms are cylindrical with short internodes and few side tubers.

Colocasia cormels and corms can be compared favourably in nutrition form with potatoes and cereals, its leaves are highly nutritious with good amount of protein and vitamins. The tuber of colocasia is rich source of starch (up to $21 \%$ of total carbohydrates), protein (above 3\%) and minerals i.e. 3.9\% (Gopalan et al., 1977). In India, colocasia is chiefly grown for human consumption and is used as food after peeled, sliced, cooked and taken with condiments and adjuncts. Colocasia is mainly cultivated for the edible tubers but the leaves and its young stacks petioles are cooked and also used for making pakoras. In some countries colocasia is used for making fermented products. The pressure cooked taro corms after being passed through strainer are allowed to ferment giving an acidic product called "poi". Taro flour is used as baby food and also used for making chips.

Colocasia (Colocasia esculenta L. Schott) is a traditional crop with a long history of cultivation in Asia and the Pacific. It is widely used as a tuber vegetable in India, whereas it is very closely associated with culture in many of the South Pacific Islands. It ranks third after cassava and yam, in terms of total production, area and consumption (Chukwu and Nwosu, 2008). In global scenario, Africa ranks first in the area and production of colocasia followed by Asia and Oceania. Despite of the importance of this crop, its cultivation anywhere in India is generally a subsistent to semi-commercial crop. In India, the major colocasia growing states are Manipur, Assam, Nagaland, Orissa, Meghalaya, Gujarat, Maharashtra, Kerala, Andhra Pradesh, Tamil Nadu, West Bengal, Uttar Pradesh and Bihar.

In Chhattisgarh, colocasia is mainly grown as a major tuber crop in tribal areas like Bastar, Kanker, Dantewada, Kawardha, Surguja and Raigarh districts. In Chhattisgarh state total area under colocasia is 7865 ha with a production of 106361 metric tonnes (Anonymous, 2012).

Weeds compete with crops for nutrients, soil moisture, sunlight and space when they are limiting, resulting in reduced yields, lower grain quality and increased production costs. The magnitude of losses depends on crop cultivars, nature and intensity of weeds, spacing, duration of weeds infestation, environmental conditions and management practices (Satao and Nalamwar, 1993). Weeds also harbour insect-pests and diseases. Weeds are an important plant resource for insects, although feeding by insects on weeds can have both positive and negative effects on crop productivity (Capinera, 2005).

Weed management through chemicals results in better growth of crop and often improves the yield of tubers than manual and mechanical means due to the elimination of mechanical damage to the plants and reduction in moisture losses from the soil that follow cultivation (Atiq et al., 2009). Chemical weed management is quicker and much less laborious by which large areas can be covered in a short time with limited amount of labour. 
Weed management practices appreciably affected root development in taro and therefore weed free period of up to 60 days was essential for proper root development (Nedunchezhiyan and Satapathy, 2003). The effect of weed interference in taro prevents the development of optimum leaf area, which in turn affects the production of necessary assimilates for tuber bulking. The presence of weeds throughout the crop growth period reduced yield of taro by $60 \%$. The looking to the importance of this crop, present investigation entitled "Response of different fertility levels and pre-emergence herbicides on weed population and benefit cost ratio of Colocasia (Colocasia esculenta var. antiquorum) will be undertaken with the following objectives: To study the effect of fertility level on growth \& yield of Colocasia, to evaluate different pre-emergence herbicides in Colocasia and to study the economics of the treatments.

\section{Materials and Methods}

Field experiment was carried out during the year 2017 under All India Co-ordinated Research Project on Tuber Crops at S.G. College of Agriculture and Research Station, Jagdalpur, IGKV, Raipur (C.G.). The experiment was laid out in split plot design with two factors namely fertility levels and different pre-emergence herbicides with three replications. Bastar plateau zone is comes under sub-humid climatic condition of Chhattisgarh. The investigation crop received $1087 \mathrm{~mm}$ rainfall during entire crop growth period. The maximum temperature varied from $40.3{ }^{\circ} \mathrm{C}$ and $40.7{ }^{\circ} \mathrm{C}$ in the third and fourth week of May during 2017. The soil of the experimental site was silty-loam to clayloam, which is locally known as Mal (midland) in this region. The field was divided into ninety plots by keeping provision for irrigation channels and distance to mark different replications as well as plots. Healthy, disease free and 20-25 g weight cormels of colocasia were used as planting material. Planting of colocasia cormels was done on 27 January 2017. Geometry was $60 \mathrm{~cm} \times 20 \mathrm{~cm}$. Pre-emergence herbicides and hand weeding was done as per treatment. Hoeing was done manually at 30 and 60 DAP to provide proper aeration for crop growth.

Fertilizers were applied as per treatment in each plot. Full dose of phosphorus and, potassium and half dose of nitrogen were applied as a basal dose during planting of corms. Remaining nitrogen was applied as a split dose at 30 and 90 days after planting. Nutrients were applied in the form of urea, single super phosphate and mutate of potash. The colocasia cormels were harvested at maturity stage. When most of the leaves begin turn yellow and fall down. The weed occurrence and intensity of different weed species were studied on $30^{\text {th }}$ and $60^{\text {th }}$ DAP. The weed study in each plot was made at randomly selected spots and for this purpose quadrate $\left(1.0 \mathrm{~m}^{2}\right)$ was used. Counting of weeds was done according to species wise and total number of weeds was recorded. The per cent composition of weed flora was estimated from weedy check plot and occurrence of dominant weeds at different intervals. Observation was recorded from center rows of each plot selected sample plants in each treatment/replication and observed mean value used for statistical analysis. The data on the different growth and yield characters were collected and analyzed statically for analysis of variance (ANOVA) fallowing the method described by Gomez and Gomez (1984).

\section{Results and Discussion}

\section{Weed flora studies}

The data pertaining to different species of weeds at 30 and 60 DAP are given in Table 1. As regards to effect of fertility levels and pre- 
emergence herbicides are affected in different weed species at 30 and 60 DAP. In fertility levels, treatment $\mathrm{F}_{5}(130 \%$ NPK) recorded significantly higher weed species i.e. Cynodon dactylon, Borreria hispida, Cyperus rutundas and Digiteria sangunalis at 30 and 60 DAP which was on par with $\mathrm{F}_{4}(115 \% \mathrm{NPK})$ at 60 DAP in Cynodon dactylon, at 30 and 60 DAP in Cyperus rotundas and at 30 in Digiteria sangunalis. It was due to weedy check allows to weeds for using sunlight, moisture and fertilizer. In case of application of preemergence herbicides treatment $\mathrm{T}_{6}$ (Weedy check) recorded superior over other treatments at 30 and 60 DAP in all species of weeds but it was found at par at 30 and 60 DAP in Cyperus rotundas and lowest weeds were recorded in treatment $\mathrm{T}_{2}$ (Pendimethalin @ $1.5 \mathrm{~kg}$ a.i. $\left.\mathrm{ha}^{-1}\right)$ at 30 and 60 DAP in all species of weeds. It might be due to application of pendimethalin suppress all weed spp. except Cyprus rotundas.

The data on weed species are presented in Table 2. The findings revealed that effect of fertility levels and pre-emergence herbicides are different species of weeds at 30 and 60 DAP found significant in different treatments. In fertility levels, treatment $\mathrm{F}_{5}(130 \% \mathrm{NPK})$ recorded significantly higher weed species i.e. Echinachloa colonum, Elucein indica, Euphorbia geniculata and other weed species at 30 and 60 DAP which was on par with $\mathrm{F}_{4}$ $(115 \% \mathrm{NPK})$ at $30 \mathrm{DAP}$ in Elucein indica. In case of pre-emergence herbicide treatment $\mathrm{T}_{6}$ (Weedy check) recorded significantly higher number of weed species among all treatments at 30 and 60 DAP and lowest weed species was recorded in treatment $\mathrm{T}_{2}$ (Pendimethalin @ $1.5 \mathrm{~kg}$ a.i. $\mathrm{ha}^{-1}$ ) at 30 and 60 DAP which, was also reported by Kebede et al., (2016).

\section{Weed density $\left(\mathrm{m}^{2}\right)$}

The data on weed density are presented in Table 3 at 30 DAP. The data revealed that treatment $\mathrm{F}_{5} \quad(130 \% \quad \mathrm{NPK})$ recorded significantly highest weed density followed by $\mathrm{F}_{4}(115 \% \mathrm{NPK})$ and lowest weed density was recorded in treatment $\mathrm{F}_{1}(70 \% \mathrm{NPK})$ in fertility levels. Whereas, in application of preemergence herbicide, treatment $\mathrm{T}_{6}$ (Weedy check) was observed maximum weed density followed by $\mathrm{T}_{4}$ (Metribuzine @) $1.5 \mathrm{~kg}$ a.i. $\mathrm{ha}^{-1}$ ) and lowest weed density were recorded in treatment $\mathrm{T}_{2}$ (Pendimethalin @ $1.5 \mathrm{~kg}$ a.i. $\left.\mathrm{ha}^{-1}\right)$. Singh et al., (2016) observed that significantly highest weed population at 30 DAP was recorded in control treatment over rest of the treatment simply because none of the weed management practices were done, in spite all the supplemental inputs (manures, fertilizers, irrigation etc.) were given like other treatment. Interaction was found nonsignificant effect in weed density due to fertility levels and application of preemergence herbicide.

The data on weed density per meter square are presented in Table 4. The findings revealed that effect of fertility levels and preemergence herbicides are weed density at 60 DAP found significantly in different treatment. As regard to fertility levels, treatment $\mathrm{F}_{5} \quad(130 \% \quad \mathrm{NPK})$ observed significantly maximum weed density followed by $\mathrm{F}_{4}(115 \% \mathrm{NPK})$ and lowest weed density was recorded treatment $\mathrm{F}_{1} \quad\left(\begin{array}{lll}70 \% & \mathrm{NPK}\end{array}\right)$. Increased level of fertilizer, increase weed density due to availability of nutrients for weed growth. In application of pre-emergence herbicide, treatment $\mathrm{T}_{6}$ (Weedy check) recorded significantly highest weed density followed by $\mathrm{T}_{4}$ (Metribuzine @) $1.5 \mathrm{~kg}$ a.i. ha ${ }^{1}$ ) and lowest weed density was observed in treatment $\mathrm{T}_{2}$ (Pendimethalin @ $1.5 \mathrm{~kg}$ a.i. ha $\left.{ }^{1}\right)$. These findings are in agreement with those of Rao et al., (2014), Bhat and Sheikh (2015) and Kadam et al., (2014). Oluwafemi (2013) and Kebede et al., (2016) observed the highest weed density was recorded in the weedy check plots. Interaction was found non-significant 
effect due to fertility levels and application of pre-emergence herbicides.

\section{Dry weight of weed}

The data pertaining to dry weight of weed at 30 DAP are given in Table 5. The data reveals that treatment $\mathrm{F}_{5}(130 \% \quad \mathrm{NPK})$ recorded significantly higher dry weight of weed followed by $\mathrm{F}_{4}(115 \% \mathrm{NPK})$ and lowest dry weight of weed was observed in treatment $F_{1}$ (70\% NPK) at 30 DAP. In case of application of pre-emergence herbicide, treatment $\mathrm{T}_{6}$ (Weedy check) was observed maximum dry weight of weed and lowest dry weight of weed was recorded in treatment $\mathrm{T}_{2}$ (Pendimethalin @ $1.5 \mathrm{~kg}$ a.i. $\mathrm{ha}^{-1}$ ).

The data on dry weight of weed are given in Table 6 . The data revealed that in different fertility levels were found significantly effect. Treatment $\mathrm{F}_{5} \quad(130 \% \quad \mathrm{NPK})$ recorded maximum dry weight of weed at 60 DAP and lowest dry weight of weed was observed $\mathrm{F}_{1}$ $(70 \% \mathrm{NPK})$ at 60 DAP. Whereas, in application of pre-emergence herbicide, treatment $\mathrm{T}_{6}$ (Weedy check) recorded higher dry weight of weed followed by $T_{4}$ (Metribuzine @) $1.5 \mathrm{~kg}$ a.i. ha ${ }^{-1}$ ) and lowest dry weight of weed was recorded in treatment $\mathrm{T}_{2}$ (Pendimethalin@1.5 kg a.i.ha ${ }^{-1}$ ).

These results are agreement with the findings of Rao et al., (2014), Kebede et al., (2016) and Singh et al., (2016). Kadam et al., (2014) observed the highest fresh and dry weight recorded in unweeded control plot because of the prolonged growth period available to weeds in the field.

Channappagoudar et al., (2007) all the weedicides significantly reduced the weed biomass compared to unweeded control. Interaction was found non-significant effect in weed density due to fertility levels and application of pre-emergence herbicide.

\section{Weed control efficiency (\%)}

The data on weed control efficiency (WCE) are presented are given in Table 7 at 30 DAP. As regards to different fertility levels, treatment $\mathrm{F}_{1}(70 \% \mathrm{NPK})$ recorded numerically higher weed control efficiency among all the treatment and lowest efficiencies were found in treatment $\mathrm{F}_{4}(115 \% \mathrm{NPK})$. In case of application of pre-emergence herbicides treatment $\mathrm{T}_{2}$ (Pendimethalin @ $1.5 \mathrm{~kg}$ a.i. $\mathrm{ha}^{-1}$ ) recorded significantly maximum weed control efficiency $(73.10 \%)$ among all the treatment and lowest weed control efficiency was observed in treatment $\mathrm{T}_{4}$ (Metribuzine @) $1.5 \mathrm{~kg}$ a.i. $\left.\mathrm{ha}^{-1}\right)$. The finding revealed that effect of fertility levels and pre-emergence herbicides at 60 DAP in different treatment. In fertility levels, treatment $\mathrm{F}_{1} \quad\left(\begin{array}{lll}70 \% & \mathrm{NPK}\end{array}\right)$ observed statically higher weed control efficiency among all the treatment and lowest WCE was found in treatment $\mathrm{F}_{4}(115 \% \mathrm{NPK})$. Whereas, in application of pre-emergence herbicides treatment $\mathrm{T}_{2}$ (Pendimethalin@ 1.5 $\mathrm{kg}$ a.i. $\mathrm{ha}^{-1}$ ) recorded significantly higher weed control efficiency among all the treatments followed by treatment $\mathrm{T}_{3}$ (Butachlor @ $1.5 \mathrm{~kg}$ a.i. $\mathrm{ha}^{-1}$ ) and lowest weed control efficiency was observed in treatment $\mathrm{T}_{4}$ (Metribuzine @) $1.5 \mathrm{~kg}$ a.i. $\mathrm{ha}^{-1}$ ). This result was analogous to the findings of Rao et al., (2014). Qadder et al., (2016) it was observed that the preemergence treatments gave better regarding weed control due to reduce competition between weed plants and crop plants. Pendimethalin applied at $12 \mathrm{ml} \mathrm{litre}^{-1}$ was found to be the most effective treatment and controlled all weeds except Cyperus rotundus. Similar findings were also observed by Bhat and Sheikh (2015). Kebede et al., (2016) reported that application of pendimethalin proved better than other herbicides in reducing the grass related weed density. This might be probably due to more effectiveness of the herbicides in controlling weeds than other treatments. 
Table.1 Effect of fertility levels and pre-emergence herbicides on different species of weeds $\left(\mathrm{m}^{2}\right)$ at 30 and 60 DAP

\begin{tabular}{|c|c|c|c|c|c|c|c|c|}
\hline Treatment & Cynodon & actylon & Borreric & hispida & Cyperu & otundas & Digitaria & angunalis \\
\hline & 30 DAP & 60 DAP & 30 DAP & 60 DAP & 30 DAP & 60 DAP & 30 DAP & 60 DAP \\
\hline Fertility lev & & & & & & & & \\
\hline$\overline{F_{1}}$ & $1.41(1.04)$ & $1.43(1.09)$ & $1.40(1.01)$ & $1.63(1.72)$ & $4.49(19.44)$ & $5.23(26.61)$ & $2.68(6.93)$ & $2.81(7.82)$ \\
\hline$\overline{F_{2}}$ & $1.52(1.36)$ & 1.55 (1.47) & $1.50(1.34)$ & 1.71 (1.99) & $4.63(20.72)$ & $5.42(28.61)$ & $2.84(7.80)$ & $2.98(8.62)$ \\
\hline$\overline{F_{3}}$ & $1.58(1.53)$ & $1.68(1.88)$ & $1.60(1.66)$ & $1.89(2.62)$ & 4.77 (21.94) & $5.56(30.22)$ & $3.01(8.81)$ & $3.21(10.08)$ \\
\hline$\overline{F_{4}}$ & $1.68(1.88)$ & $1.74(2.08)$ & $1.72(2.09)$ & $2.01(3.11)$ & $4.90(23.28)$ & $5.73(32.22)$ & $3.09(9.40)$ & $3.36(10.99)$ \\
\hline$\overline{F_{5}}$ & $1.78(2.22)$ & $1.81(2.33)$ & $1.81(2.41)$ & $2.16(3.74)$ & $5.11(25.39)$ & $5.93(34.47)$ & $3.23(10.27)$ & $3.53(12.09)$ \\
\hline$S E m \pm$ & 0.01 & 0.02 & 0.01 & 0.02 & 0.08 & 0.09 & 0.05 & 0.03 \\
\hline$C D$ at $5 \%$ & 0.04 & 0.07 & 0.05 & 0.07 & 0.25 & 0.30 & 0.18 & 0.11 \\
\hline Pre- & herbicides & & & & & & & \\
\hline$\overline{T_{1}}$ & $1.65(1.72)$ & $1.60(1.59)$ & $1.67(1.80)$ & $1.97(2.91)$ & $4.87(22.80)$ & $5.71(31.80)$ & $3.26(9.71)$ & $3.14(8.93)$ \\
\hline $\mathbf{T}_{2}$ & $1.31(0.73)$ & $1.35(0.86)$ & $1.03(0.06)$ & 1.47 (1.19) & $4.15(16.33)$ & $4.63(20.50)$ & $1.15(0.51)$ & $2.18(3.86)$ \\
\hline$\overline{T_{3}}$ & $1.43(1.07)$ & $1.52(1.34)$ & $1.56(1.46)$ & $1.73(2.06)$ & $4.38(18.27)$ & $5.49(29.33)$ & $2.89(7.43)$ & $2.67(6.25)$ \\
\hline$\overline{T_{4}}$ & $1.75(2.07)$ & $1.79(2.23)$ & $1.74(2.06)$ & $2.05(3.24)$ & $5.25(26.60)$ & $5.87(33.60)$ & $3.47(11.21)$ & $3.36(10.31)$ \\
\hline$\overline{T_{5}}$ & $1.52(1.31)$ & $1.57(1.51)$ & $1.58(1.53)$ & $1.88(2.57)$ & $4.60(20.27)$ & $5.66(31.20)$ & $3.03(8.25)$ & $2.86(7.29)$ \\
\hline$\overline{T_{6}}$ & $1.93(2.74)$ & $2.01(3.09)$ & $2.06(3.29)$ & $2.18(3.85)$ & $5.43(28.67)$ & $6.08(36.13)$ & $3.96(14.75)$ & $4.88(22.87)$ \\
\hline$S E m \pm$ & 0.01 & 0.02 & 0.02 & 0.03 & 0.07 & 0.09 & 0.06 & 0.03 \\
\hline$C D$ at $5 \%$ & 0.04 & 0.06 & 0.05 & 0.07 & 0.21 & 0.26 & 0.16 & 0.09 \\
\hline
\end{tabular}

The observations are square root transformed $(\sqrt{ } x+0.5)$. Figures in parentheses indicate the square root transformed value. $F_{1}: 70 \%$ NPK, $F_{2}: 85 \% N P K, F_{3}:$ 100\% NPK, F $F_{4}: 115 \%$ NPK, $F_{5}: 130 \%$ NPK, $T_{1}$ : Atrazine @ $1.5 \mathrm{~kg}$ a.i. ha ${ }^{-1}, T_{2}:$ Pendimethalin @ $1.5 \mathrm{~kg}$ a.i. ha $a^{-1}, T_{3}:$ Butachlor @ 1.5 kg a.i.ha ${ }^{-1}, T_{4}:$ Metribuzine @ $0.25 \mathrm{~kg}$ a.i. $\mathrm{ha}^{-1}, T_{5}$ : Hand weeding, $T_{6}:$ Weedy check (Control) 
Table.2 Effect of fertility levels and pre-emergence herbicides on different species of weeds (m-2) at 30 and 60 DAP

\begin{tabular}{|c|c|c|c|c|c|c|c|c|}
\hline \multirow[t]{2}{*}{ Treatment } & \multicolumn{2}{|c|}{ Echinochloa clonum } & \multicolumn{2}{|c|}{ Elucein indica } & \multicolumn{2}{|c|}{ Euphorbia geniculata } & \multicolumn{2}{|c|}{ Other weed spp. } \\
\hline & 30 DAP & 60 DAP & 30 DAP & 60 DAP & 30 DAP & 60 DAP & 30 DAP & 60 DAP \\
\hline \multicolumn{9}{|c|}{ Fertility levels } \\
\hline F1 & $2.38(5.15)$ & $2.39(5.04)$ & $2.11(3.63)$ & $2.24(4.27)$ & $1.59(1.60)$ & $1.54(1.44)$ & $2.29(4.75)$ & $1.84(2.68)$ \\
\hline F2 & $2.55(5.91)$ & $2.59(5.99)$ & $2.23(4.16)$ & $2.36(4.82)$ & $1.69(1.93)$ & $1.69(1.92)$ & $2.40(5.33)$ & $1.95(3.11)$ \\
\hline F3 & $2.64(6.41)$ & $2.74(6.81)$ & $2.32(4.55)$ & $2.49(5.53)$ & $1.82(2.36)$ & $1.84(2.48)$ & $2.51(5.86)$ & $2.09(3.67)$ \\
\hline F4 & $2.77(7.10)$ & $2.90(7.69)$ & $2.43(5.06)$ & $2.66(6.39)$ & $1.93(2.78)$ & $1.96(2.93)$ & $2.59(6.34)$ & $2.24(4.28)$ \\
\hline F5 & $2.90(7.83)$ & $3.04(8.54)$ & $2.51(5.47)$ & $2.82(7.32)$ & $2.06(3.29)$ & $2.08(3.39)$ & $2.71(7.03)$ & $2.37(4.92)$ \\
\hline$S E m \pm$ & 0.04 & 0.03 & 0.03 & 0.03 & 0.02 & 0.02 & 0.03 & 0.02 \\
\hline$C D$ at $5 \%$ & 0.14 & 0.11 & 0.10 & 0.09 & 0.06 & 0.05 & 0.09 & 0.05 \\
\hline \multicolumn{9}{|c|}{ Pre-emergence herbicides } \\
\hline T1 & $2.94(7.71)$ & $2.79(6.87)$ & $2.49(5.24)$ & $2.52(5.41)$ & $1.93(2.77)$ & $1.87(2.53)$ & $2.86(7.22)$ & $2.13(3.57)$ \\
\hline $\mathbf{T 2}$ & $1.35(0.98)$ & $1.93(2.80)$ & $1.71(1.99)$ & $1.78(2.29)$ & $1.41(1.03)$ & $1.45(1.13)$ & $1.03(0.07)$ & $1.37(0.95)$ \\
\hline T3 & $2.51(5.33)$ & $2.43(4.97)$ & $2.10(3.43)$ & $2.16(3.69)$ & $1.61(1.64)$ & $1.64(1.75)$ & $2.22(4.01)$ & $1.70(1.95)$ \\
\hline T4 & $3.10(8.67)$ & $2.98(7.91)$ & $2.66(6.09)$ & $2.88(7.39)$ & $2.01(3.06)$ & $2.00(3.03)$ & $3.05(8.38)$ & $2.24(4.05)$ \\
\hline T5 & $2.69(6.29)$ & $2.59(5.75)$ & $2.14(3.62)$ & $2.25(4.09)$ & $1.81(2.29)$ & $1.74(2.05)$ & $2.54(5.51)$ & $2.02(3.10)$ \\
\hline T6 & $3.29(9.89)$ & $3.68(12.60)$ & $2.83(7.09)$ & $3.47(11.13)$ & $2.13(3.55)$ & $2.25(4.11)$ & $3.31(10.00)$ & $3.12(8.80)$ \\
\hline$S E m \pm$ & 0.06 & 0.03 & 0.03 & 0.03 & 0.02 & 0.02 & 0.03 & 0.02 \\
\hline CD at $5 \%$ & 0.16 & 0.07 & 0.09 & 0.09 & 0.06 & 0.06 & 0.09 & 0.06 \\
\hline
\end{tabular}

The observations are square root transformed $(\sqrt{ } x+0.5)$. Figures in parentheses indicate the square root transformed value. F1: 70\% NPK, F2: $85 \%$ NPK, F3: 100\% NPK, F4: 115\% NPK, F5: 130\% NPK, T1: Atrazine @ 1.5 kg a.i.ha-1, T2: Pendimethalin @ $1.5 \mathrm{~kg}$ a.i. ha-1, T3: Butachlor @ 1.5 kg a.i.ha-1, T4: Metribuzine @0.25 kg a.i. ha-1,T5: Hand weeding, T6: Weedy check (Control) 
Table.3 Interaction between fertility levels x pre- emergence herbicide on weed density $\left(\mathrm{m}^{2}\right)$ of colocasia field at $30 \mathrm{DAP}$

\begin{tabular}{|l|c|c|c|c|c|c|c|}
\hline \multicolumn{1}{|c|}{ Treatment } & $\mathrm{T}_{1}$ & $\mathrm{~T}_{2}$ & $\mathrm{~T}_{3}$ & $\mathrm{~T}_{4}$ & $\mathrm{~T}_{5}$ & $\mathrm{~T}_{6}$ & Mean F \\
\hline $\mathrm{F}_{1}$ & $6.98(47.77)$ & $4.15(16.37)$ & $5.89(33.80)$ & $7.52(55.73)$ & $6.38(39.83)$ & $8.29(67.87)$ & $6.54(43.56)$ \\
\hline $\mathrm{F}_{2}$ & $7.43(54.30)$ & $4.51(19.43)$ & $6.16(37.03)$ & $8.01(63.20)$ & $6.64(43.17)$ & $8.67(74.13)$ & $6.90(48.54)$ \\
\hline $\mathrm{F}_{3}$ & $7.79(59.70)$ & $4.70(21.10)$ & $6.57(42.20)$ & $8.30(68.03)$ & $7.13(49.93)$ & $8.87(77.77)$ & $7.23(53.12)$ \\
\hline $\mathrm{F}_{4}$ & $8.07(64.20)$ & $4.99(23.94)$ & $6.95(47.37)$ & $8.63(73.47)$ & $7.40(53.77)$ & $9.26(84.83)$ & $7.55(57.94)$ \\
\hline $\mathrm{F}_{5}$ & $8.36(68.87)$ & $5.35(27.68)$ & $7.33(52.70)$ & $9.01(80.23)$ & $7.72(58.70)$ & $9.81(95.30)$ & $7.93(63.91)$ \\
\hline Mean T & $7.73(58.97)$ & $4.74(21.70)$ & $6.58(42.62)$ & $8.29(68.13)$ & $7.06(49.08)$ & $8.98(79.98)$ \\
\hline & $\mathrm{F}$ & $\mathrm{T}$ & $\mathrm{Fx} \mathrm{T}$ & & & \\
\hline SEm & 0.06 & 0.07 & 0.15 & & & \\
\hline CD at 5\% & 0.20 & 0.20 & $\mathrm{NS}$ & & & \\
\hline
\end{tabular}

Table.4 Interaction between fertility levels x pre- emergence herbicide on weed density $\left(\mathrm{m}^{2}\right)$ of colocasia field at 60 DAP

\begin{tabular}{|c|c|c|c|c|c|c|c|}
\hline Treatment & $\mathbf{T}_{1}$ & $\mathbf{T}_{2}$ & $\mathbf{T}_{3}$ & $\mathbf{T}_{4}$ & $\mathrm{~T}_{5}$ & $T_{6}$ & Mean F \\
\hline$F_{1}$ & $7.20(50.93)$ & $5.08(24.90)$ & $6.20(37.60)$ & $7.79(56.77)$ & $6.79(45.17)$ & $9.31(85.70)$ & $7.06(50.68)$ \\
\hline$F_{2}$ & $7.63(57.27)$ & $5.62(30.57)$ & $6.79(45.07)$ & $8.10(64.60)$ & $7.17(50.47)$ & $9.61(91.30)$ & $7.48(56.54)$ \\
\hline $\mathbf{F}_{4}$ & $8.49(71.20)$ & $6.06(35.77)$ & $7.72(58.53)$ & 8.87 (77.67) & $8.12(64.97)$ & $10.54(110.03)$ & $8.30(69.69)$ \\
\hline $\mathrm{F}_{5}$ & $8.80(76.40)$ & $6.55(42.00)$ & 8.07 (64.10) & $9.32(85.90)$ & $8.45(70.47)$ & $11.09(122.00)$ & $8.71(76.81)$ \\
\hline Mean T & $8.01(63.61)$ & $5.86(33.57)$ & $7.20(51.33)$ & $8.51(71.77)$ & $7.63(57.56)$ & $10.16(102.59)$ & \\
\hline$S E m \pm$ & 0.08 & 0.07 & 0.19 & & & & \\
\hline$C D$ at $5 \%$ & 0.25 & 0.19 & NS & & & & \\
\hline
\end{tabular}

The observations are square root transformed $(\sqrt{ } x+0.5)$. Figures in parentheses indicate the square root transformed value. $F_{1}: 70 \%$ NPK, $F_{2}: 85 \%$ NPK, $F_{3}:$


Metribuzine @ $0.25 \mathrm{~kg}$ a.i. ha ${ }^{-1}, T_{5}$ : Hand weeding, $T_{6}$ : Weedy check (Control) 
Table.5 Interaction between fertility levels x pre- emergence herbicide on dry weight of weed at 30 DAP

\begin{tabular}{|c|c|c|c|c|c|c|c|}
\hline Treatment & $\mathbf{T}_{1}$ & $\mathbf{T}_{2}$ & $\mathbf{T}_{3}$ & $\mathbf{T}_{4}$ & $\mathbf{T}_{5}$ & $\mathrm{~T}_{6}$ & Mean F \\
\hline$F_{1}$ & $2.40(4.76)$ & $1.62(1.64)$ & $2.09(3.38)$ & $2.56(5.57)$ & $2.23(3.98)$ & $2.79(6.79)$ & $2.28(4.35)$ \\
\hline $\mathbf{F}_{2}$ & $2.53(5.43)$ & $1.71(1.94)$ & $2.17(3.70)$ & $2.70(6.32)$ & $2.30(4.32)$ & $2.90(7.41)$ & $2.39(4.85)$ \\
\hline$\overline{F_{3}}$ & $2.63(5.97)$ & $1.75(2.11)$ & $2.28(4.22)$ & $2.79(6.80)$ & 2.45 (4.99) & $2.96(7.78)$ & $2.48(5.31)$ \\
\hline $\mathbf{F}_{4}$ & $2.72(6.42)$ & $1.84(2.39)$ & $2.40(4.74)$ & $2.89(7.35)$ & $2.53(5.38)$ & $3.07(8.48)$ & $2.58(5.79)$ \\
\hline $\mathbf{F}_{5}$ & $2.81(6.89)$ & $1.93(2.77)$ & $2.50(5.27)$ & $3.00(8.02)$ & $2.62(5.87)$ & $3.24(9.53)$ & $2.68(6.39)$ \\
\hline \multirow[t]{2}{*}{ Mean T } & $2.62(5.89)$ & $1.77(2.17)$ & $2.29(4.26)$ & $2.79(6.81)$ & $2.43(4.91)$ & $3.00(8.00)$ & \\
\hline & $\mathrm{F}$ & $\mathrm{T}$ & $\mathrm{F} \times \mathrm{T}$ & & & & \\
\hline$S E m \pm$ & 0.02 & 0.04 & 0.26 & & & & \\
\hline$C D$ at $5 \%$ & 0.07 & 0.11 & NS & & & & \\
\hline
\end{tabular}

Table.6 Interaction between fertility levels x pre- emergence herbicide on dry weight of weed at 60 DAP

\begin{tabular}{|c|c|c|c|c|c|c|c|}
\hline Treatment & $\mathbf{T}_{1}$ & $\mathbf{T}_{2}$ & $\mathbf{T}_{3}$ & $\mathbf{T}_{4}$ & $\mathrm{~T}_{5}$ & $\mathrm{~T}_{6}$ & Mean F \\
\hline$F_{1}$ & $2.48(5.17)$ & $1.86(2.51)$ & $2.18(3.78)$ & $2.64(5.98)$ & $2.34(4.52)$ & $3.10(8.61)$ & $2.43(5.10)$ \\
\hline $\mathbf{F}_{2}$ & $2.59(5.71)$ & $2.02(3.09)$ & $2.35(4.51)$ & $2.73(6.50)$ & $2.46(5.06)$ & $3.19(9.21)$ & $2.56(5.68)$ \\
\hline $\mathbf{F}_{3}$ & $2.70(6.31)$ & $2.11(3.47)$ & $2.48(5.14)$ & $2.86(7.20)$ & $2.59(5.71)$ & $3.39(10.50)$ & $2.69(6.39)$ \\
\hline $\mathbf{F}_{4}$ & $2.85(7.14)$ & $2.14(3.58)$ & $2.62(5.87)$ & $2.96(7.78)$ & $2.74(6.50)$ & $3.48(11.10)$ & $2.80(6.99)$ \\
\hline$\overline{F_{5}}$ & $2.94(7.65)$ & $2.25(4.07)$ & $2.74(6.48)$ & $3.10(8.63)$ & $2.84(7.09)$ & $3.65(12.36)$ & $2.92(7.71)$ \\
\hline Mean T & $2.71(6.40)$ & $2.08(3.35)$ & $2.47(5.16)$ & $2.86(7.22)$ & $2.59(5.78)$ & $3.36(10.35)$ & \\
\hline & $\mathrm{F}$ & $\mathrm{T}$ & $\mathrm{F} \times \mathrm{T}$ & & & & \\
\hline$S E m \pm$ & 0.03 & 0.03 & 0.29 & & & & \\
\hline$C D$ at $5 \%$ & 0.09 & 0.09 & NS & & & & \\
\hline
\end{tabular}

The observations are square root transformed $(\sqrt{ } x+0.5)$. Figures in parentheses indicate the square root transformed value. $F_{1}: 70 \% N P K, F_{2}: 85 \% N P K, F_{3}$ :

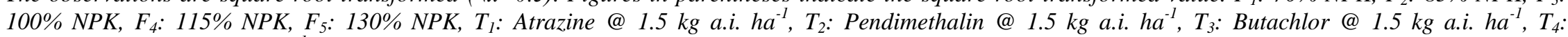
Metribuzine @ $0.25 \mathrm{~kg}$ a.i. ha ${ }^{-1}, T_{5}$ : Hand weeding, $T_{6}$ : Weedy check (Control) 
Table.7 Interaction between fertility levels x pre- emergence herbicide on weed control efficiency at 30 and 60 DAP

\begin{tabular}{|c|c|c|c|c|c|c|c|c|c|c|c|c|c|c|}
\hline & \multicolumn{7}{|c|}{ Weed control efficiency at 30 DAP } & \multicolumn{7}{|c|}{ Weed control efficiency at 60 DAP } \\
\hline Treatment & $\mathbf{T}_{1}$ & $\mathbf{T}_{2}$ & $\mathbf{T}_{3}$ & $\mathbf{T}_{4}$ & $\mathbf{T}_{5}$ & $\mathbf{T}_{6}$ & Mean F & $\mathbf{T}_{1}$ & $\mathbf{T}_{2}$ & $\mathbf{T}_{3}$ & $\mathbf{T}_{4}$ & $\mathbf{T}_{5}$ & $\mathbf{T}_{6}$ & Mean F \\
\hline $\mathbf{F}_{1}$ & 29.37 & 76.15 & 50.52 & 18.98 & 41.69 & 0.00 & 36.12 & 39.93 & 70.81 & 56.02 & 30.62 & 47.70 & 0.00 & 40.85 \\
\hline$\overline{F_{2}}$ & 27.00 & 73.74 & 49.98 & 14.85 & 41.88 & 0.00 & 34.58 & 37.67 & 66.40 & 50.42 & 29.08 & 45.08 & 0.00 & 38.11 \\
\hline $\mathbf{F}_{3}$ & 23.71 & 72.83 & 46.06 & 13.24 & 35.96 & 0.00 & 31.97 & 40.14 & 66.75 & 50.74 & 31.28 & 45.60 & 0.00 & 39.09 \\
\hline$F_{4}$ & 24.30 & 71.80 & 44.21 & 13.38 & 36.60 & 0.00 & 31.72 & 36.48 & 68.27 & 47.92 & 30.94 & 42.17 & 0.00 & 37.63 \\
\hline$F_{5}$ & 27.93 & 70.96 & 44.82 & 16.23 & 38.26 & 0.00 & 33.03 & 38.22 & 67.18 & 47.53 & 30.31 & 42.64 & 0.00 & 37.65 \\
\hline Mean T & 26.46 & 73.10 & 47.12 & 15.34 & 38.88 & 0.00 & 33.48 & 38.49 & 67.88 & 50.53 & 30.45 & 44.64 & 0.00 & 38.67 \\
\hline Factor & \multicolumn{3}{|c|}{$\mathrm{F}$} & \multicolumn{3}{|c|}{$\mathrm{T}$} & $\mathrm{F} \times \mathrm{T}$ & \multicolumn{3}{|c|}{$\mathrm{F}$} & \multicolumn{3}{|c|}{$\mathrm{T}$} & $\mathrm{F} \times \mathrm{T}$ \\
\hline SEm & \multicolumn{3}{|c|}{1.00} & \multicolumn{3}{|c|}{1.06} & 2.45 & \multicolumn{3}{|c|}{1.14} & \multicolumn{3}{|c|}{0.94} & 2.79 \\
\hline$C D$ at $5 \%$ & \multicolumn{3}{|c|}{ NS } & \multicolumn{3}{|c|}{3.01} & NS & \multicolumn{3}{|c|}{ NS } & \multicolumn{3}{|c|}{2.67} & NS \\
\hline
\end{tabular}

$F_{1}: 70 \% N P K, F_{2}: 85 \% N P K, F_{3}: 100 \% N P K, F_{4}: 115 \% N P K$ and $F_{5}: 130 \% N P K, T_{1}:$ Atrazine @ $1.5 \mathrm{~kg}$ a.i. ha ${ }^{-1}, T_{2}:$ Pendimethalin @ $1.5 \mathrm{~kg}$ a.i. ha ${ }^{-1}, T_{3}:$ Butachlor@1.5 kg a.i. ha $a^{-1}, T_{4}:$ Metribuzine@ $0.25 \mathrm{~kg}$ a.i. ha ${ }^{-1}, T_{5}:$ Hand weeding and $T_{6}$ : Weedy check (Control)

Table.8 Interaction effect of fertilizer and herbicide on net return and benefit cost ratio of colocasia

\begin{tabular}{|c|c|c|c|c|c|c|c|c|c|c|c|c|c|c|}
\hline & \multicolumn{7}{|c|}{ Net return (Rs) } & \multicolumn{7}{|c|}{ Benefit cost (B:C) ratio } \\
\hline Treat. & $\mathbf{T}_{1}$ & $\mathbf{T}_{2}$ & $\mathbf{T}_{3}$ & $\mathbf{T}_{4}$ & $\mathbf{T}_{5}$ & $\mathbf{T}_{6}$ & Mean F & $\mathbf{T}_{1}$ & $\mathbf{T}_{2}$ & $\mathbf{T}_{3}$ & $\mathbf{T}_{4}$ & $\mathbf{T}_{5}$ & $T_{6}$ & Mean F \\
\hline $\mathbf{F}_{1}$ & 135582 & 160045 & 145062 & 121024 & 133049 & 26479 & 120207 & 2.83 & 3.11 & 2.92 & 2.63 & 2.63 & 1.36 & 2.58 \\
\hline $\mathbf{F}_{2}$ & 147281 & 172161 & 162594 & 136472 & 151497 & 47761 & 136294 & 2.96 & 3.24 & 3.11 & 2.81 & 2.83 & 1.64 & 2.76 \\
\hline $\mathrm{F}_{3}$ & 171061 & 199274 & 184291 & 156919 & 173528 & 63207 & 158047 & 3.24 & 3.55 & 3.36 & 3.06 & 3.07 & 1.83 & 3.02 \\
\hline $\mathbf{F}_{4}$ & 203178 & 250558 & 235574 & 187536 & 219061 & 79491 & 195900 & 3.62 & 4.16 & 3.97 & 3.42 & 3.57 & 2.03 & 3.46 \\
\hline$F_{5}$ & 232793 & 270173 & 248523 & 209484 & 238260 & 88939 & 214695 & 3.95 & 4.35 & 4.08 & 3.66 & 3.76 & 2.13 & 3.66 \\
\hline Mean T & 177979 & 210442 & 195209 & 162287 & 183079 & 61175 & 165029 & 3.32 & 3.68 & 3.49 & 3.12 & 3.17 & 1.80 & 3.10 \\
\hline Factor & \multicolumn{3}{|c|}{$\mathrm{F}$} & \multicolumn{3}{|c|}{$\mathrm{T}$} & $\mathrm{F} \times \mathrm{T}$ & \multicolumn{3}{|c|}{$\mathrm{F}$} & \multicolumn{3}{|c|}{$\mathrm{T}$} & $\mathrm{F} \times \mathrm{T}$ \\
\hline$S E m \pm$ & \multicolumn{3}{|c|}{3699} & \multicolumn{3}{|c|}{5279} & 9062 & & 0.05 & & \multicolumn{3}{|c|}{0.07} & 0.19 \\
\hline$C D$ at $5 \%$ & \multicolumn{3}{|c|}{12252} & \multicolumn{3}{|c|}{15041} & NS & \multicolumn{3}{|c|}{0.17} & \multicolumn{3}{|c|}{0.19} & NS \\
\hline
\end{tabular}

$F_{1}: 70 \% N P K, F_{2}: 85 \% N P K, F_{3}: 100 \% N P K, F_{4}: 115 \% N P K$ and $F_{5}: 130 \% N P K, T_{1}:$ Atrazine @ $1.5 \mathrm{~kg}$ a.i. ha ${ }^{-1}, T_{2}:$ Pendimethalin @ 1.5 kg a.i. ha $a^{-1}, T_{3}:$ Butachlor @ $1.5 \mathrm{~kg}$ a.i. ha ${ }^{-1}, T_{4}:$ Metribuzine @ $0.25 \mathrm{~kg}$ a.i. ha ${ }^{-1}, T_{5}:$ Hand weeding and $T_{6}:$ Weedy check (Control) 
Interaction was found non-significant effect in weed control efficiency due to fertility levels and application of pre-emergence herbicide.

\section{Economics}

\section{Net returns ( $\left.\operatorname{Rs~ha}^{-1}\right)$}

The data on net return of colocasia are presented in Table 8 . The data recorded in net return of colocasia shows that treatment $\mathrm{F}_{5}$ $(130 \%$ NPK) recorded maximum net return among all the treatment followed in $\mathrm{F}_{3}(115 \%$ NPK) and lowest net return was recorded in treatment $\mathrm{F}_{1}(70 \% \mathrm{NPK})$ in fertility level. Also reported by Nautiyal et al., (2016) and Joshi et al., (2017) and in pre-emergence herbicide, treatment $\mathrm{T}_{2}$ (Pendimethalin @ 1.5 $\mathrm{kg}$ a.i. $\mathrm{ha}^{-1}$ ) recorded significantly highest net return among the all treatment and lowest net return was observed in $\mathrm{T}_{6}$ which was control. Padmapriya et al., (2008) observed that weed management caused significant improvement in economic returns of cassava. Also reported by Kumar et al., (2012) found that application of pendimethalin along with hand weeding proved to be economical. In case of interaction between fertility levels and preemergence herbicides it was found nonsignificant effect due to different levels of treatments.

\section{Benefit cost ratio}

The data recorded in $\mathrm{B}$ : $\mathrm{C}$ ratio are presented in Table 8. Treatment $\mathrm{F}_{5} \quad(130 \% \quad \mathrm{NPK})$ recorded significantly higher benefit cost ratio of colocasia among all the treatment and lowest $\mathrm{B}$ : $\mathrm{C}$ ratio was recorded treatment $\mathrm{F}_{1}$ (70\% NPK) in fertility level. Akther et al., (2016) observed benefit-cost ratio was found maximum from with $25 \%$ higher than the recommended fertilizer dose. Also similar results reported by Joshi et al., (2017). Whereas, in pre-emergence herbicide, treatment $\mathrm{T}_{2}$ (Pendimethalin @ $1.5 \mathrm{~kg}$ a.i. $\mathrm{ha}^{-1}$ ) recorded significantly highest benefit cost ratio while, treatment $\mathrm{T}_{3}$ (Butachlor@ $1.5 \mathrm{~kg}$ a.i. $\mathrm{ha}^{-1}$ ) recorded on par and lowest B: $C$ ratio was recorded in treatment $T_{6}$ (Weedy check). Similar findings were observed by Singh et al., (2016). Rao et al., (2014) reported that the maximum $\mathrm{B}$ : $\mathrm{C}$ ratio was achieved with Butachlor@1.5 kg a.i. ha ${ }^{-1}$ in gladiolus. Interaction between fertility levels and pre-emergence herbicide on benefit cost ratio of colocasia found unaffected due to different treatments.

Findings of experiment conclude that the herbicide application as pre-emergence of pendimethalin treatment gave better results regarding weed control and effect of weed control on growth and yield of colocasia. While, increasing rat of fertilizer were recorded significantly higher weed population. Among pre-emergence herbicide treatment, Pendimethalin was found very effective treatment and gave maximum weed control efficiency, net return $\mathrm{ha}^{-1}$ and finally B: C ratio. It can be concluded from the finding of this experiment that pre-emergence application of pendimethalin @ $1.5 \mathrm{~kg}$ a.i. ha $^{-1}$ fallowed by Butachlor @ 1.5 kg a.i. ha ${ }^{-1}$ is the best proposition for acceptable weed management and results higher return under irrigated condition in the study area. In one year experiment, application of pendimethalin @ $1.5 \mathrm{~kg}$ a.i. ha ${ }^{-1}$ can be suggested to farmers for effective weed management particularly where grassy and broad leave weeds are predominant.

\section{Acknowledgement}

The authors thankfully acknowledge to the S. G. College of Agriculture and Research Station, Jagdalpur (C.G.) for the facilities provided for undertaking this experiment at the centre. The authors express their sincere gratitude to Dr. James George, Project Coordinator, AICRP on Tuber Crops for 
providing facility and budget for undertaking this experiment.

\section{References}

Anonymous, 2012. National Horticulture Mission, Annual Action Plan for Horticulture Development in Chhattisgarh, Raipur (C.G.). pp. 50.

Atiq, A. K., Muhammad, Q. K. and Muhammad, S. J. 2009. Evaluation of Weed Management Techniques in Autumn Potato Crop. J. Weed Sci. Res., 15(1): 31-43.

Bhat, Z. A. and Sheikh, M. Q. 2015. Evaluation of different herbicides in gladiolus (Gladiolus grandiflorus L.). Int. J. Tech. Enhancements and Emerging Engineering Res., 3(4): 5659.

Capinera, J. L. 2005. Relationship between insect pests and weeds an evolutionary perspective. Weed Science, 53(6): 892901.

Chang, T. K. 1958. Dispersal of taro in Asia. Ann. Ass. Am. Geog., 48:255-256.

Channappagoudar, B. B., Biradar, N.R., Bharmagoudar, T.D. and Koti, R. V. 2007. Crop weed competition and chemical control of weeds in potato. Karnataka J. Agric. Sci., 20(4): 715718.

Chukwu, G. O. and Nwosu, K. I. 2008. Cocoyam rebirth. The renaissance of a giant crop. Paper presented at the $17^{\text {th }}$ Annual conference of Nigeria Rural Sociological Association at NRCRI, Umudike. pp. 11.

Gomez, K. A. and Gomez, A. A. 1984. Statistical procedure for Agricultural Research. John Wiley and Sons Publication New Delhi, 2nd edition.

Gopalan, C. B. Y., Shastri, R. and Balasubramaniam, S. C.1977. Nutritive value of Indian food. National institute of nutrition ICMR, Hyderabad, India. pp.19.

Joshi, K. K., Sharma, G. K., Chandrakar, T. and Shankar, D. 2017. Influence of Graded Doses of Organic and Inorganic Nutrients on Growth, Yield and Economics of Tikhur (Curcuma aungustifolia Roxb.) in Inceptisol of Bastar Plateau. Int. J. Curr. Microbiol. App. Sci., 6(10): 1269-1277.

Kadam, G. B., Kumar, G., Taraknathsaha, R. K., Tiwari, A. K. and Kumar, R. 2014. Evaluation of pre-emergence herbicides in gladiolus (Gladiolus). Ind. J. Agri. Sci., 84 (12): 106-109.

Kebede, G., Sharma, J. J. and Dechassa, N. 2016. Evaluation of chemical and cultural methods of weed management in potato (Solanum tuberosum L.). J. Natural Sci. Res., 6(5): 28-47.

Keleny, G. P. 1962. The origin and introduction of the basic food crop of New Guinea People. Papua New Guinea Agric. J., 15: 7-13.

Kumar, A., Sharma, B. C. and Kumar, J. 2012. Integrated weed management in gladiolus. Indian J. W. Sci., 44(3): 181182.

Nautiyal, N., Tiwari, D., Upadhyay, S. and Chauhan, R. S. 2016. Effect of nitrogen levels and plant spacing on growth and yield of turmeric. Inter. J. App. and Pure Sci. and Agri., 2(10):184-192.

Nedunchezhiyan, M. and Satapathy, B. S. 2003. Effect of weed management practices on root development in taro (Colocasia esculenta (L.) Schott). J. Root Crops, 29(1): 60-64.

Oluwafemi, A. B. 2013. Evaluation of weed management strategies in cocoyam (Colocasia esculentus L. schott) production in Ado-Ekiti. Int. Res. J. Agri. Sci. and Soil Sci., 3(2): 38-42.

Padmapriya, S., Balasubramanian, R. and Sathiyamurthy, V. A. 2008. Weed management studies in cassava 
(Manihot esculenta L.) intercropping systems under irrigated conditions. J. Hortl. Sci. 3 (2): 141-145.

Purseglove, J. W. 1972. Tropical crops: Monocotyledons. Wiley, New York.

Qadeer, A., Ali Z., Ahmad, H. M., Qasam, M., and Toor S. 2016. Invasion of different weeds on Gladiolus and their control by herbicides, Plant Gene and Trait, 7(6): 1-9.

Rao, K. D., Kameswari, L. P., Girwani, A. and Baby Rani, T. 2014. Chemical weed management in gladiolus (Gladiolus grandiflorus). Agric. Sci. Digest., 34 (3): 194 - 198.

Satao, R. N. and Nalamwar, R. V. 1993. Studies on uptake of nitrogen, phosphorus and potassium by weeds and sorghum as influenced by integrated weed control. Integrated weed management for sustainable agriculture, pp. 103-107. In: Proceedings of an Indian Society of Weed Sci. Inte. Symp., 18-20 November, Hisar, India.

Singh, R.S., Singh, P. P. and Narayan, A. 2016. Effect of Weed Management Practices on Weed Dynamics, Yield and Economics of Sweet Potato (Ipomoea batatas L.). J. Root Crops, 42(2): 47-51.

Vinning, G. 2003. Select markets for taro, sweet potato and yam. RIRDC Project No. UCQ- 13A.

\section{How to cite this article:}

Markam, R.K., Deo Shankar and Thakur, A.K. 2018. Response of Different Fertility Levels and Pre-Emergence Herbicides on Weed Population and Benefit Cost Ratio of Colocasia (Colocasia esculenta Var. antiquorum). Int.J.Curr.Microbiol.App.Sci. 7(09): 2764-2776. doi: https://doi.org/10.20546/ijcmas.2018.709.343 